\title{
Process-based model in adolescence. Analyzing police legitimacy and juvenile delinquency within a legal socialization framework
}

\author{
Olalla $\mathrm{Baz}^{1} \cdot$ Esther Fernández-Molina ${ }^{1}$
}

(C) Springer Science+Business Media B.V. 2017

\begin{abstract}
The empirical evidence on the process-based model of self-regulation shows that procedural justice evaluations and the perceived legitimacy of authorities impact law-abiding behavior. However, few studies analyze this theory from the perspective of adolescent legal socialization. The present study aims to examine the process-based model and other socializing agents such as family, school and peers that may have an effect on it. The sample comprised 2041 youths residing in Spain, aged between 13 and 18 years. The data form part of the Third International Self-Report Delinquency Study (ISRD-3). Multiple linear regression analyses were conducted to predict police legitimacy and juvenile delinquency. The results reveal that police legitimacy perceptions are not only influenced by procedural justice, but also by parental monitoring, school attachment, and delinquent peers. Moreover, perceptions of police legitimacy, parental monitoring, and delinquent peers predict juvenile delinquency. These findings complement and add new explanatory factors to the process-based model.
\end{abstract}

Keywords Legal socialization · Police legitimacy Procedural justice $\cdot$ Juvenile delinquency

\section{Introduction}

Criminological research is currently exploring new approaches to responding to traditional questions and addressing long-standing challenges. Why some people commit crimes and others do not continues to be a matter of debate, as along with the role played by social control institutions in this process. This issue is especially relevant when considering the juvenile

Esther Fernández-Molina

Esther.Fdez@uclm.es

Olalla Baz

Olalla.Baz@uclm.es

1 Criminology Research Centre, University of Castilla-La Mancha, Benjamín Palencia, Campus Universitario s/n, 02071 Albacete, Spain 
justice system. The progress made in science in the last decade is helping in the review of juvenile justice, proposing new effective practices aimed at controlling juvenile delinquency (Boonie et al. 2013). However, there are still major problems that need to be addressed, especially the role of legal institutions in regulatory compliance. It has been found that social control models based on threat and punishment are not as effective as other alternatives. In fact, compliance theories do not only include instrumental strategies but also models regarding normative considerations on the good and bad points of noncompliance (Hough et al. 2013a). One of the most empirically developed compliance theories in recent years has been the process-based model of self-regulation, which emphasizes the role played by public views of the legitimacy of legal authorities. These judgments about legitimacy are supposedly enhanced when people believe that legal authorities use fair procedures in their interactions with the public. At the same time, this perceived legitimacy results in greater public compliance and cooperation with the justice system (Tyler 1990, 2003).

Despite the empirical development of this field of research, far fewer studies use samples of youths than samples of adults to test these hypotheses (see, for example, Akinlabi 2015; Hinds 2007; Reisig and Lloyd 2009). This is surprising given that attitudes towards the law and authorities are part of a legal socialization process that begins before adulthood. As well as the formal authorities, this process is also influenced by other socializing agents such as family, school or friends, which transmit a certain orientation toward authority and compliance with social norms (Fagan and Tyler 2005). Taking adolescent legal socialization as its reference, this study aims to examine the process-based model of self-regulation, using a representative sample of youths residing in Spain. To this end, it is necessary to consider not only the variables traditionally used in Tyler's model (procedural justice, legitimacy, and compliancedelinquency-cooperation ${ }^{1}$ ), but also those relating to socializing agents that influence adolescents: family and school attachment, parental monitoring, and delinquent peers. The data form part of the Third International Self-Report Delinquency Study (ISRD-3) contains items focused on police legitimacy perceptions. This work presents the results of two multiple linear regression models that predict, respectively, police legitimacy judgments and offending among youths.

\section{Theoretical background}

\section{Tyler's process-based model}

The process-based model is a social psychological approach developed in the literature by Tyler (1990). In contrast to strategies responding to instrumental motivations (e.g., deterrence), the Tylerian model focuses on the internalization of values favoring normative compliance with the law and collaboration with the justice system.

Legitimacy of legal authorities plays an important role in the drive for law-abiding behavior (Tyler, 2006), and it has been a subject of much theoretical and empirical study as a measure of attitudes toward authority. Research on institutional legitimacy in the field of social sciences is grounded in the work of Max Weber (1964). This author was the first to identify the concept of

\footnotetext{
${ }^{1}$ Although some studies have used a delinquency scale (Cavanagh and Cauffman 2015), most have tested the degree of regulatory compliance (Reisig et al. 2014) and cooperation with the authorities (Dirikx and Van den Bulck 2014).
} 
legitimacy as a citizens' belief in the ruling order, which depends on how the state exercises power. Thus, legitimacy of laws or authorities results in the internalization of the obligation to obey it as if it were a social value.

Beetham (1991) approached legitimacy as a perception based on the interactions between the different state institutions and the individuals subject to their decisions. Nonetheless, he believes that shared moral values are indispensable to justify imposing norms in a society. In criminological research, institutional legitimacy has been analyzed as a multidimensional empirical construct associated with the above-mentioned conceptual statements. It has been operationalized to include three dimensions: institutional trust or support, obligation to obey, ${ }^{2}$ and moral alignment (Jackson and Gau 2016).

In Tyler's model, the legitimacy of authorities is strengthened if people perceive their procedures to be fair. This is the reason why this model is widely known as the procedural justice theory. The literature identifies two specific elements that make up the procedural justice construct: quality of decision-making and quality of treatment (Blader and Tyler 2003; Tyler and Fagan 2008). On the one hand, citizens value objectivity and neutrality as two essential factors in ensuring justice in an authority's decision-making process. On the other hand, treating the parties involved in a conflict with dignity and respect, and giving them the opportunity to have their opinions taken into account in decision-making, are key elements in upholding the fairness of procedural actions. When legal institutions ignore these criteria of justice, individuals feel they are not valued as members of society, which leads to an erosion of mutual identification. In this vein, Jackson et al. (2012) state, 'disrespectful treatment and unfair decision-making erode the extent to which citizens value (...) group authorities, as well as the subsequent identification they have with the set of rules that legal authorities enforce' (p. 3).

Research on the process-based model has traditionally focused on adult populations. However, in recent years, studies in this regard have been conducted with youths in different social contexts, such as the United States (Fagan and Tyler 2005), the United Kingdom (Hough 2013), Canada (Greene et al. 2010; Sprott and Greene 2010), Australia (Hinds 2007, 2009), Jamaica (Reisig and Lloyd 2009), Belgium (Dirikx and Van den Bulck 2014), and Nigeria (Akinlabi 2015). This field of research is important since attitudes toward legal authority are acquired from childhood onward through a legal socialization process.

\section{Legal socialization and its importance in adolescence}

The previously mentioned line of research is complementary to the idea of legal socialization, that is, the process whereby individuals assimilate the laws implemented in a society and understand how legal institutions work (Tapp and Levine 1974). Thus, in accordance with our previous discussion of Tyler's model, in this legal socialization process individuals develop beliefs and attitudes toward authority that lead them to respect the legal system of their own volition. Although legal socialization is initiated during childhood, adolescence is a key period in this process for two notable reasons.

Firstly, the changes that take place in moral reasoning are relevant to the study of legitimacy perceptions of legal authorities. Drawing on Kohlberg (1992), cognitive development plays a

\footnotetext{
${ }^{2}$ Bottoms and Tankebe (2012) suggest that the obligation to obey is not part of the legitimacy concept. Considering an authority to be legitimate is only one of the factors leading to feeling the obligation to obey, among others such as fear or dull compulsion.
} 
role in orientation toward authority, and thus it makes more sense to analyze these attitudes in adolescence than in earlier developmental stages. Kohlberg's research defines different stages of moral reasoning linked to psychological development. The third stage begins in adolescence, when moral reasoning is still not autonomous due to adolescents' need for approval from others. However, in the fourth stage, the awareness of the obligation to obey the law and legal authorities emerges, because this is beneficial for maintaining social order. In light of the above, we should only allude to perceptions of institutional legitimacy in the terms defined by Weber (1964) as the fourth stage of moral reasoning, which does not appear until mid or late adolescence (Emler and Reicher 1987).

Secondly, youths' perceptions of the law and legal authorities are a product of different social interactions that, in adolescence, may be direct or vicarious. The literature on youths' perceptions of authority traditionally uses their opinions of the police in studies on the processbased model, attitudes, and legal socialization. If minors are arrested for committing a crime, their first contact with the justice system is through the police, who are responsible for reading them their rights and conducting prior administrative proceedings (Bernuz 2014). Moreover, the police are probably one of the most visible authorities due to extensive exposure in the media and citizens' daily contact with them in various situations (Boda and Medve-Bálint 2015). Hence, adolescents have access to a larger amount of information stemming from their own experience or what they have learnt from parents, friends, and acquaintances.

Furthermore, apart from possible interactions they might have had with legal authority, individuals generate beliefs and attitudes to authority and norms through the influence of informal socializing agents such as teachers, family, and peers (Fagan and Tyler 2005).

A number of studies have analyzed the variables related to social bonds between parents and children, finding that enhanced family attachment is associated with positive attitudes to the police (Ferdik et al. 2014; Flexon et al. 2009; Sargeant and Bond, 2015; Wu et al. 2015). The literature has shown the importance of these bonds by comparing the attitudes of minors toward authority with those of their parents, finding certain similarities between them (Cavanagh and Cauffman 2015; Sargeant and Bond 2015; Wolfe et al. 2016). Another factor, albeit not the subject of much empirical research, is that the higher the parental monitoring, the greater the adolescents' perception of authority as legitimate (Fagan and Tyler 2005).

A high level of school or university attachment is also associated with positive attitudes toward the police (Ferdik et al. 2014, 2016; Flexon et al. 2009; Lurigio et al. 2009; Wu et al. 2015). Other scholars have analyzed the effects of factors such as the fairness of teachers' behavior and the legitimation of school authority, finding a positive relationship between these variables and the evaluation of institutional authorities like the police (Gouveia-Pereira et al. 2003). Conversely, other researchers have found that involvement in a delinquent peer group generates negative attitudes toward the police (Brick et al. 2009; Ren et al. 2016).

This body of research on young people's attitudes toward formal authority suggests the need to complement the process-based model of self-regulation with new explanatory factors. Although criminological evidence on the association of these socializing agents with juvenile delinquency is now undeniable, the literature has paid little attention to its influence on adolescents' perceptions of institutional legitimacy (Cavanagh and Cauffman 2015; Wolfe et al. 2016), when possibly some of these attitudes influence criminal behavior and are acquired through the same legal socialization process. Therefore, this work proposes to evaluate the influence of formal and informal agents of socialization on police legitimacy and juvenile delinquency.

Additionally, this study analyzes the process-based model from a legal socialization standpoint in the Spanish context, since the great majority of the evidence obtained comes 
from the Anglo-Saxon context. The role of family, school, peers, and police authority in the socialization process of Spanish adolescents may have a different scope than that which has been demonstrated in other countries. For example, in Spain, as in other countries of southern Europe, the family is a very important axis of support. Thus, the extended family, which in other societies has lost its influence, has an undeniable importance in the socialization of young people in Mediterranean countries (Moreno 2001). Similarly, the influence of school institutions does not have the same effect in all cultures. In the Spanish context, the school is conceived as an institution in which knowledge is acquired, hence educational research has paid more attention to this aspect than to non-cognitive ones (Krüger et al. 2015). With regard to the influence of friends, Spain is a country in which there are practically no juvenile criminal gangs in the strict sense, since most of the youth groups arise as a space of relation between equals in which they find their emotional independence (Bartolomé-Gutiérrez and RecheaAlberola 2006). Finally, the political evolution that this country has suffered in the last 40 years has caused Spanish society to be more critical of police authority than in other countries in which this institution generates a greater consensus (Newburn and Reiner 2012).

\section{Research questions}

The aim of this study is to analyze the process-based model of regulation within the framework of adolescent legal socialization in the Spanish context. We address two research questions: (1) Do procedural justice used by the police, parental monitoring, family attachment, school attachment, and delinquent peers predict adolescents' perceptions of police legitimacy? And (2) if the influence of these factors relating to socializing agents is taken into account, does police legitimacy predict juvenile delinquency?

\section{Data}

The data form part of the Third International Self-Report Delinquency Study (ISRD-3). The ISRD project is an international collaborative study that gathers information on juvenile delinquency and victimization at different ages to observe and compare differences and trends across the participating countries. To undertake this work, a subsample of 2041 youths residing in Spain was selected. The respondents were recruited in two cities, Madrid and Albacete, using multistage random cluster sampling. We chose the school as our first unit of analysis and the class as our second. Students were aged from 13 to 18 years, with a mean age of 15.33. The sample comprises $49.1 \%$ males and $50.9 \%$ females.

The data were collected using a self-report questionnaire prepared by the ISRD project. Official permission to survey minors was obtained, anonymous and voluntary participation was ensured, and informed consent was required from parents. The fieldwork was undertaken from February 2015 to May 2016.

\section{Variables}

The following paragraphs describe the operationalization of the variables used in the study. Table 1 shows the descriptive statistics for all these variables. The multiple linear regression 
Table 1 Descriptive statistics of variables

\begin{tabular}{lllll}
\hline Analyzed variables & Min. & Max. & Mean & Std. deviation \\
2003 Procedural justice & 3 & 12 & 6.66 & 2.24 \\
Police legitimacy & 3 & 15 & 8.89 & 2.81 \\
Parental monitoring & 7 & 35 & 27.11 & 6.25 \\
Parental attachment & 4 & 20 & 17.12 & 2.88 \\
School attachment & 3 & 16 & 10.42 & 2.83 \\
Delinquent peers & 0 & 5 & 1.05 & 1.16 \\
Juvenile delinquency & 0 & 14 & 1.93 & 1.86 \\
Control variables & Min. & Max. & Mean/\%* & Std. deviation \\
Police contact & 0 (no) & 1 (yes) & $12 \%$ & - \\
Gender & 0 (male) & 1 (female) & $50.9 \%$ & - \\
City of residence & 0 (Madrid) & 1 (Albacete) & $44.9 \%$ & - \\
Age & 13 & 18 & 15.33 & 1.30 \\
Socioeconomic status & 2 & 14 & 8.20 & 2.06 \\
Immigrant status & 0 (native) & 1 (minority) & $17.5 \%$ & - \\
Victimization status & 0 & 7 & .98 & 1.17 \\
\hline
\end{tabular}

*When the variable is categorical, the percentage of respondents refers to category 1

models predicting police legitimacy and juvenile delinquency are shown in Tables 2 and 3, respectively.

Procedural justice Drawing on Tyler (1990), three questions on the quality of decisionmaking and the quality of police interpersonal treatment were used to form this variable: (a) 'Would you say the police generally treat young people with respect?', (b) 'How often would you say the police make fair decisions when dealing with young people?', (c) 'How often would you say the police explain their decisions and actions to young people?' Each item was measured using a four-point Likert scale ranging from almost never to almost always. The highest scores on this scale represent the most positive evaluation of police procedural justice $($ Cronbach's alpha $=.80)$.

Table 2 Multiple linear regression model predicting police legitimacy

\begin{tabular}{|c|c|c|c|}
\hline Predictors & $\mathrm{b}$ & SE & $\beta$ \\
\hline \multicolumn{4}{|l|}{ Control variables } \\
\hline Police contact $(0=$ no $)$ & -.695 & .170 & $-.080 * * *$ \\
\hline Gender $(0=$ male $)$ & -.357 & .103 & $-.063 * *$ \\
\hline City of residence $(0=$ Madrid $)$ & .021 & .109 & .004 \\
\hline Age & -.080 & .042 & -.037 \\
\hline Socioeconomic status & .035 & .025 & .025 \\
\hline Immigrant status $(0=$ native $)$ & .398 & .146 & .050 \\
\hline Victimization status & -.008 & .047 & -.003 \\
\hline \multicolumn{4}{|l|}{ Independent variables } \\
\hline Procedural justice & .616 & .024 & $.490 * * *$ \\
\hline Parental monitoring & .034 & .009 & $.075^{* * *} *$ \\
\hline Parental attachment & .009 & .020 & .009 \\
\hline School attachment & .087 & .019 & $.088 * * *$ \\
\hline Delinquent peers & -.116 & .050 & $-.048 *$ \\
\hline Intercept & $4.07 * * *$ & .793 & - \\
\hline F-test & $94.65 * * *$ & & \\
\hline $\mathrm{R}^{2}$ & .35 & & \\
\hline
\end{tabular}

(b) Unstandardized regression coefficient, (ES) Standard error, ( $\beta$ ) Standardized regression coefficient $* p<.05 ; * * p<.01 ; * * * p<.001$ (two-tailed test) 
Table 3 Multiple linear regression model predicting juvenile delinquency

\begin{tabular}{lccc}
\hline Predictors & $\mathrm{b}$ & $\mathrm{SE}$ & $\beta$ \\
\hline Control variables & & & $.257^{* *}$ \\
Police contact $(0=\mathrm{no})$ & 1.47 & .107 & $-.068^{* *}$ \\
Gender $(0=$ male) & -.255 & .065 & -.033 \\
City of residence $(0=$ Madrid $)$ & -.118 & .068 & .013 \\
Age & .018 & .026 & -.025 \\
Socioeconomic status & -.023 & .016 & $-.059^{*}$ \\
Immigrant status $(0=$ native $)$ & -.312 & .092 & $.105^{* *}$ \\
Victimization status & .167 & .030 & -.031 \\
Independent variables & & & $-.128^{* *}$ \\
Procedural justice & -.026 & .018 & -.002 \\
Parental monitoring & -.038 & .006 & -.028 \\
Parental attachment & -.001 & .012 & $.330^{* *}$ \\
School attachment & -.018 & .012 & $-.087^{* *}$ \\
Delinquent peers & .529 & .031 & - \\
Police legitimacy & -.057 & .014 & .500 \\
Intercept & $3.09 * *$ & & \\
F-test & $115.37 * * *$ & .42 & \\
R & & & \\
\hline
\end{tabular}

(b) Unstandardized regression coefficient, (ES) Standard error, ( $\beta$ ) Standardized regression coefficient $* p<.05 ; * * p<.01 ; * * * p<.001$ (two-tailed test)

Police legitimacy Following the theoretical concept of legitimacy as a moral alignment between police and citizens (Van Damme et al. 2015), three items were used to measure this construct: (a) 'The police generally have the same sense of right and wrong as I do', (b) 'The police are appreciative of how young people think', (c) 'I generally support how the police usually act'. Given the importance of strengthening confidence in the measures used to capture the views of young people (Hinds 2007), the research teams that are part of the ISRD-3 have tried to improve the measurement of legitimacy and adjust the wording of some questions of the fifth European Social Survey in order to make them more user-friendly (Marshall et al. 2013). Responses were scored on a five-point Likert scale ranging from agree strongly to disagree strongly. The items were recoded for the highest scores to indicate the greatest perceived policy legitimacy (Cronbach's alpha $=.81$ ).

Parental monitoring Drawing on the approach proposed by Stattin and Kerr (2000), to measure monitoring we used seven statements related to parental knowledge of children's activities and children's communication with their parents: (a) 'My parents know where I am when I go out', (b) 'My parents know what I am doing when I go out', (c) 'My parents know what friends I am with when I go out', (d) 'I tell my parents who I spend time with', (e) 'I tell my parents how I spend my money', (f) 'I tell my parents where I am most afternoons after school', (g) 'I tell my parents what I do with my free time'. The items were rated on a fivepoint Likert scale ranging from almost always to almost never, and were recoded for the highest scores to reflect high parental monitoring (Cronbach's alpha $=.87$ ).

Family attachment Four items were selected for the formation of this variable: (a) 'I get along just fine with my father', (b) 'I get along just fine with my mother', (c) 'I can easily get emotional support and care from my parents', (d) 'I would feel very bad disappointing my parents'. Responses were scored on a five-point Likert scale ranging from totally agree to 
totally disagree. The highest scores need to represent the highest levels of attachment, hence the items were recoded (Cronbach's alpha $=.71)$.

School attachment Four items were used to assess adolescents' attachment to their schools: (a) 'If I had to move I would miss my school', (b) 'Most mornings I like going to school', (c) 'I like my school', (d) 'Our classes are interesting'. Responses were measured on a four-point Likert scale ranging from I fully agree to I fully disagree. Responses were subsequently recoded for the highest scores to indicate highest school attachment (Cronbach's alpha $=.76$ ).

Delinquent peers We created a variety scale by selecting five questions from the survey questionnaire with a dichotomous response format (no-yes). Students had to report whether their friends had exhibited any of the following criminal acts: 'I have friends who...' (a) '... used soft or hard drugs like weed, hash, ecstasy, speed, heroin or coke', (b) '...have stolen things from a shop or department store', (c) '... have entered a building without permission to steal something', (d) '...have threatened somebody with a weapon or beaten someone up, just to get their money or other things', (e) '...have beaten someone up or hurt someone badly with something like a stick or a knife'. Thus, the higher the number of criminal acts undertaken by friends, the higher the levels of delinquency in the peer group (Cronbach's alpha $=.63$ ).

Juvenile delinquency We used 14 items from the survey with a dichotomous response format (no-yes) to calculate variety scores referring to different criminal acts: 'Have you ever in your life...' (a) '... painted on a wall, train, subway or bus?', (b) '...damaged something on purpose, such as a bus shelter, a window, a car or a seat in the bus or train?', (c) '...stolen something from a shop or department store?', (d) ‘...broken into a building to steal something?', (e) '...stolen a bicycle?', (f) ‘...stolen a motorbike or a car?', (g) ‘...stolen something off or from of a car?', (h) '... used a weapon, force or threat of force to get money or things from someone?', (i) '... stolen something from a person without force or threat?', (j) '...carried a weapon, such as a stick, knife, gun or chain?', (k) '...taken part in a group fight in a football stadium, on the street or other public place?', (l) '...beaten someone up or hurt someone with a stick or knife so badly that the person was injured?', (m) '...illegally downloaded music or films from the Internet?', (n) '... sold any drugs or helped someone selling drugs?'. Consequently, the higher the number of crimes committed by juveniles, the higher the level of delinquency (Cronbach's alpha =.72).

Control variables On the basis of previous research, some variables were controlled for their influence on attitudes toward the police and juvenile delinquency in earlier studies. These variables are contact with the police, gender, city of residence, age, socioeconomic status, immigrant minority status, and victimization status.

\section{Analytical strategy}

Two multiple linear regression equations were used to meet the aims of this study. Before proceeding with the multivariate analysis, we examined the zero-order correlations between the study variables. None of the correlations yielded a value of more than 0.60 , indicating there were no serious multicollinearity problems between the independent variables that could

$\overline{3}$ This item refers to noncriminal antisocial behavior. 
interfere with a linear regression analysis. The same was deduced from the collinearity statistics shown in the appendix (mean VIF $=1.18$ for the first model; mean VIF $=1.24$ for the second model).

The aim of the first multiple linear regression was to answer the question of whether evaluations of procedural justice and other factors relating to socializing agents impact on young people's perceptions of police legitimacy. Thus, police legitimacy was used as the dependent variable, and procedural justice, parental monitoring, family attachment, school attachment, and delinquent peers were taken as the independent variables.

The second multiple linear regression is aimed at answering the question of whether police legitimacy and other factors relating to socialization predict delinquency in youths. Consequently, we took juvenile delinquency as the dependent variable while procedural justice, police legitimacy, parental monitoring, family attachment, school attachment, and delinquent peers were used as independent variables. In this case, a nonnormality distribution was found in the dependent variable. According to Farrington and Loeber (2000), 'forcing variables to be normally distributed may distort their true nature - e.g., if delinquency truly is a skewed variable' (p. 102). Rather than transform the juvenile delinquency variable for it to meet the assumption of normality, it was decided to use the nonparametric bootstrapping method to recalculate the standard errors of the regression equation, as recommended by researchers (Sabia 2016).

\section{Results}

The first model accounts for 35\% of the variance in adolescents' perception of police legitimacy. Of the control variables, only contact with the police and gender were significant. In this sense, youths who had some contact with the police as a result of having committed illegal acts tend to attribute little legitimacy to the police as an authority $\beta=-.080 ; p<.001)$. The results also show that females' perceptions of legitimacy are more negative $(\beta=-.063$; $p<.01)$.

With regard to the different scales analyzed, procedural justice evaluations, parental monitoring, school attachment, and having delinquent peers predict young people's perceived police legitimacy. The factor with most predictive capacity is procedural justice $(\beta=.490$; $p<.001$ ), the greater the belief in the police being fair in their procedures, the greater will be the adolescents' perceived legitimacy. Similarly, although the regression coefficient weights are much lower, the greater the parental monitoring and school attachment, the greater will be the adolescents' legitimacy perceptions of police authority $(\beta=.075 ; p<.001$ and $\beta=.088$; $p<.001)$. By contrast, and as expected, having a delinquent peer group negatively impacts the consideration of the police as a legitimate institution $(\beta=.048 ; p<.05)$.

The second model accounts for $42 \%$ of the variance in the adolescents' self-reported delinquency. In this case, three of the control variables were significant: police contact, gender, and immigrant status. The sign of the significant coefficients reveals that young males commit more criminal acts $(\beta=-.068 ; p<.01)$, as do youths with police contact $(\beta=.257 ; p<.01)$, those not belonging to immigrant minorities $(\beta=-.059 ; p<.05)$, and those who have been victims of crime $(\beta=.105 ; p<.01)$. Moreover, having delinquent peers is the variable with the highest predictive capacity $(\beta=.330 ; p<.01)$. Thus, the greater the number of criminal acts in the peer group, the higher the adolescents' self-reported offending. Although the influence is lower than for the previous variable, young people exposed to more parental monitoring are 
less likely to be involved in criminal conduct $(\beta=-.128 ; p<.01)$. Considering police authority a legitimate institution also lowers juvenile delinquency $(\beta=-.087 ; p<.01)$. However, procedural justice evaluations of the police do not influence offending among youths $(\beta=-.031 ; p>.05)$.

Despite these results, we have decided to verify the existence of an indirect relationship between procedural justice and juvenile delinquency through the mediation of police legitimacy following the method discussed by Baron and Kenny (1986). As seen in the first model, procedural justice is the main predictor of police legitimacy perceptions $(\beta=.490 ; p<.001)$. Likewise, the second model reveals the relationship between police legitimacy and juvenile delinquency $(\beta=-.087 ; p<.01)$. If we perform a regression that predicts juvenile delinquency without introducing police legitimacy as an independent variable, procedural justice emerges as significant $(\beta=-.074 ; p<.01)$. Finally, when police legitimacy is introduced in the same model as an independent variable along with procedural justice, the latter does not become significant $(\beta=-.031 ; p>.05)$. These steps lead us to conclude that there is an indirect relationship between procedural justice and juvenile delinquency through police legitimacy perceptions (Baron and Kenny 1986).

\section{Discussion}

This study confirms and validates the process-based model of self-regulation in the adolescent population residing in Spain. It identifies other socialization factors that, besides having an impact on young people's criminal behavior, also influence the development of their perceptions of institutional legitimacy.

Focusing on Tyler's model, the study confirms that belief in fair police procedures leads youths to perceive the police as a legitimate institution. This finding is not surprising, since when Tyler $(1990,2003)$ developed his theory, these evaluations on the quality of decisionmaking and quality of interpersonal treatment were the most influential on legitimacy perceptions of the police and other legal authorities. A large number of studies replicate the same finding in young and adult populations (see, for example, Akinlabi 2015; Ferdik et al. 2014; Reisig and Lloyd 2009; Van Damme et al. 2015). Thus, the contributions of this research line suggest that the legitimation process of formal control institutions is influenced by certain justice criteria that young people value in authorities' actions regardless of the social setting studied. In this sense, it is worth noting that the lowest evaluation of the police is emitted by adolescents who have directly interacted with them. Hence, in future longitudinal studies, it would be interesting to assess the specific effect of these interactions on adolescents' perceptions.

Furthermore, the perception of the police as a legitimate authority is a protective factor against criminal behavior and, consequently, encourages the legal socialization process conducive to compliance (see, for example, Fagan and Tyler 2005; Hough et al. 2013b; Reisig et al. 2014; Tyler 1990). It is worth highlighting that the literature tends to use generic measures of the intention to comply with the law. Hence, studies that use specific items of self-reported behavior to measure delinquency or normative compliance with the law lend even greater relevance to the hypotheses of the process-based model (see, for example, Fagan and Tyler 2005; Reisig et al. 2014) due to the differences between individuals' intentions and final behavior (Fishbein and Azjen 1975).

The results of the second regression also indicate that procedural justice evaluations do not directly influence juvenile delinquency. However, the analysis developed later confirms the 
existence of an indirect relationship between both variables through police legitimacy perceptions, revealing that the greater the procedural justice evaluations of the police, the lower juvenile delinquency. Some studies had already noted that often the effects of procedural justice occur through the mediation of legitimacy. For instance, Murphy and her colleagues analyzed the variables that influence young people's cooperative behavior in the Australian context. They found that the full impact of procedural justice in the degree of cooperation with the police was mediated by legitimacy perceptions of this institution, leaving without effect the direct relationship between both variables (Murphy 2015; Murphy and Gaylor 2010).

Furthermore, our analysis shows that this legitimation process is related to the influence generated by other socializing agents in the formation of attitudes toward the law and legal authorities. The present study shows that police legitimacy perceptions might be transmitted through the different roles played by these agents.

Parental monitoring significantly influences perceptions of the police, fostering moral alignment with this authority figure. To the best of our knowledge, the only work with a similar finding was developed by Fagan and Tyler (2005). The parental monitoring scale used in this study not only considers the dimension of knowledge (knowing what children do) but also that of communication (what parents and children talk about). It can be suggested that when monitoring involves open communication between parents and children and knowledge of their activities, it encourages interiorization of conventional norms and values, thereby facilitating secondary socialization regarding legitimacy perceptions of authorities as it occurs with normative compliance. Nonetheless, this is nothing more than a theoretical hypothesis that should be tested in future empirical studies. Additionally, although we do not know whether there is a direct relationship between the two variables, this work confirms that there exists a relationship between reduced parental monitoring and increased juvenile delinquency, as is well known in criminology (Bendezú et al. 2016; Stattin and Kerr 2000).

School also has an effect on the formation of young people's attitudes as it occupies an intermediate position as a figure of authority due to being informal and approachable like the family but having, at the same time, legal and formal foundations that regulate its functioning. There are studies on the relationship between attachment and commitment to school and adolescents' positive attitudes toward the police (Flexon et al. 2009; Lurigio et al. 2009; Wu et al. 2015), although it should be noted that they do not use items regarding perceptions of legitimacy.

Conversely, our analysis shows that spending time with delinquent peers partly explains young people's negative perceptions of police legitimacy. This is in line with previous findings in the literature on attitudes toward police authority. As a source of socialization, a peer group involved in antisocial and criminal behavior may breed negative attitudes toward the justice system (Nivette et al. 2015), as demonstrated, for example, in their perceptions of the legitimacy of formal authorities. This finding is not only a result of direct or vicarious contact with the police, but also of an adolescent's commitment to a group that rejects the norms and forms of conventional authority (Schuck 2013). Furthermore, the present study finds a relationship between being surrounded by delinquent friends and criminal behavior, which is supported in the criminological literature (Hoeben et al. 2016). This is not only a consequence of the transmission of attitudes but also of other learning processes such as imitation, vicarious reinforcement or peer pressure (Warr and Stafford 1991).

In short, the results of this study allow us to assess the possible influence of certain variables on the legitimation of legal authorities and their impact on youths' criminal behavior. 
Apart from the specific influence of procedural justice, which this study finds to be considerable, there are also other factors worthy of consideration when conducting a more extensive study of how attitudes toward authority and laws are generated among adolescents. According to research on development, morality is not shaped autonomously; it depends on expectations generated by the peer group and the influence of other socializing agents. This hypothesis is supported by the present study since, although we are unable to explain how this influence is exerted, both legitimacy perceptions and juvenile delinquency are affected by these variables. This idea is also corroborated by recent findings in the field of neuroscience (Steinberg 2014) showing that, despite the ability of adolescents to understand norms and the workings of justice, their attitudes and behavior are immensely influenced by others due to their psychosocial immaturity.

The validation of the process-based model in a juvenile population necessitates all these actors being taken into account as they determine the shaping of adolescents' attitudes and behavior. Consequently, given the theoretical background and the empirical evidence presented in this work, for future research it would be interesting to explore further the legal socialization process and the factors affecting it.

\section{Limitations}

Despite the significance of our results, this study has a series of limitations. First, adolescents tend either to under-report or to over-report their involvement in criminal behavior. To correct this possible methodological bias, future studies should control for social disability in response. Second, the cross-sectional nature of the data implies that the causal direction between variables responds simply to theoretical and not methodological criteria. We suggest the development of more longitudinal and experimental studies to confirm the process-based model in different social contexts. Third, the observable measures used to evaluate procedural justice and legitimacy are based on research previously conducted with adult participants. New survey designs and complementary qualitative methodologies would help to explain the process of attitude formation toward authority and its relationship with socializing agents during adolescence. The final limitation of this research refers to theoretical considerations. With regard to socializing agents, this work has only studied family, school, and peer group, without focusing on other agents, such as the media, which undoubtedly exert an influence on the transmission of attitudes toward the justice system (Dirikx et al. 2013; Dirikx and Van den Bulck 2014). Furthermore, not all learning is related to socializing experience, and, hence, adolescents' levels of moral and legal reasoning should be considered in future research (Cohn et al. 2012). Analyzing each of these factors in a single model would provide a more extensive understanding of the process-based model in adolescence within the legal socialization framework.

\section{Conclusion}

In the present study, we have examined the process-based model of self-regulation in the Spanish context from the approach of adolescent legal socialization using a sample of 2041 youths who participated in the ISRD-3. The findings obtained from a first regression model reveal that high evaluations of procedural justice, more parental monitoring, high degree of 
school attachment, and less delinquency among peers predict high police legitimacy perceptions. Moreover, the results of a second linear regression model indicate that less parental monitoring, more peer delinquency, and low police legitimacy perceptions predict high levels of delinquency among youths. Procedural justice does not have a direct effect on juvenile delinquency in the second model, but additional findings show that its effects on delinquency are indirect through police legitimacy perceptions. Thus, this work not only validates the procedural justice theory among youths in the Spanish context, but also identificates other factors related to family, school, and peers that influence youths' legal socialization.

Acknowledgments This research was carried out with funding from the regional government of Castilla-La Mancha, Spain (PPOII-2014-009-P). The authors thank the ISRD-3 Steering Comittee, as well as the Spanish ISRD-3 members Cristina Rechea and Raquel Bartolomé for their support in this research. The authors also thank other members of the Criminology Research Centre for participating in data collection.

\section{Appendix}

Table 4 Zero-order correlations among variables

\begin{tabular}{|c|c|c|c|c|c|c|c|}
\hline Analyzed variables & 1 & 2 & 3 & 4 & 5 & 6 & 7 \\
\hline 1. Procedural justice & 1 & & & & & & \\
\hline 2. Police legitimacy & .567 & 1 & & & & & \\
\hline 3. Parental monitoring & .261 & .258 & 1 & & & & \\
\hline 4. Parental attachment & .149 & .151 & .369 & 1 & & & \\
\hline 5. School attachment & .209 & .233 & .308 & .223 & 1 & & \\
\hline 6. Delinquent peers & -.292 & -.304 & -.348 & -.177 & -.198 & 1 & \\
\hline 7. Juvenile delinquency & -.286 & -.258 & -.304 & -.160 & -.154 & .532 & 1 \\
\hline
\end{tabular}

Table 5 Variance inflation factors (VIF) for both linear regression models

\begin{tabular}{lcc}
\hline Predictors & Police legitimacy & Juvenile delinquency \\
\hline Control variables & & \\
Police contact & 1.20 & 1.21 \\
Gender & 1.05 & 1.05 \\
City of residence & 1.17 & 1.17 \\
Age & 1.17 & 1.17 \\
Socioeconomic status & 1.04 & 1.04 \\
Immigrant status & 1.06 & 1.07 \\
Victimization status & 1.22 & 1.22 \\
Independent variables & & \\
Procedural justice & 1.19 & 1.57 \\
Parental monitoring & 1.37 & 1.38 \\
Parental attachment & 1.28 & 1.28 \\
School attachment & 1.17 & 1.18 \\
Delinquent peers & 1.34 & 1.34 \\
Police legitimacy & - & 1.56 \\
\hline
\end{tabular}




\section{References}

Akinlabi, O. M. (2015). Young people, procedural justice and police legitimacy in Nigeria. Policing and Society. https://doi.org/10.1080/10439463.2015.1077836.

Baron, R. M., \& Kenny, D. A. (1986). The moderator-mediator variable distinction in social psychological research: Conceptual, strategic, and statistical considerations. Journal of Personality and Social Psychology, 51(6), 1173-1182.

Bartolomé-Gutiérrez, R., \& Rechea-Alberola, C. (2006). Violent youth groups in Spain. Young, 14(4), 323-342.

Beetham, D. (1991). The Legitimation of power. Basingstoke: Palgrave Macmillan.

Bendezú, J. J., Pinderhughes, E. E., Hurley, S. M., McMahon, R. J., \& Racz, S. J. (2016). Longitudinal relations among parental monitoring strategies, knowledge, and adolescent delinquency in a racially diverse at-risk sample. Journal of Clinical Child \& Adolescent Psychology. https://doi.org/10.1080/15374416.2016.1141358.

Bernuz, M. J. (2014). La legitimidad de la justicia de menores: Entre justicia procedimental y justicia social. InDret, 1, 1-25.

Blader, S. L., \& Tyler, T. R. (2003). A four-component model of procedural justice: Definig the meaning of a "fair" process. Personality and Social Psychology Bulletin, 29(6), 747-758.

Boda, Z., \& Medve-Bálint, G. (2015). How perceptions and personal contact matter: The individual-level determinants of trust in police in Hungary. Policing and Society. https://doi.org/10.1080/10439463.2015.1053479.

Boonie, R., Johnson, R., Chemers, B., \& Schuck, J. (2013). Reforming juvenile justice. A developmental approach. Washington, D.C.: The National Academies Press.

Bottoms, A., \& Tankebe, J. (2012). Beyond procedural justice: A dialogic approach to legitimacy in criminal justice. The Journal of Criminal Law and Criminology, 102(1), 119-253.

Brick, B. T., Taylor, T. J., \& Esbensen, F. A. (2009). Juvenile attitudes towards the police: The importance of subcultural involvement and community ties. Journal of Criminal Justice, 37(5), 488-495.

Cavanagh, C., \& Cauffman, E. (2015). Viewing law and order: Mothers' and sons' justice system legitimacy attitudes and juvenile recidivism. Psychology, Public Policy, and Law, 21(4), 432-441.

Cohn, E. S., Trinkner, R. J., Rebellon, C. J., Van Gundy, K. T., \& Cole, L. M. (2012). Legal attitudes and legitimacy: Extending the integrated legal socialization model. Victims and Offenders: An International Journal of Evidence-based Research, Policy, and Practice, 7(4), 385-406.

Dirikx, A., \& Van den Bulck, J. (2014). Media use and process-based model for police cooperation. An integrative approach towards explaining adolescents' intentions to cooperate with the police. British Journal of Criminology, 54(2), 344-365.

Dirikx, A., Gelders, D., \& Van den Bulck, J. (2013). Adolescent perceptions of the performance and fairness of the police: Examining the impact of television exposure. Mass Communication and Society, 16(1), 109-132.

Emler, N., \& Reicher, S. (1987). Orientations to institutional authority in adolescence. Journal of Moral Education, 16(2), 108-116.

Fagan, J., \& Tyler, T. R. (2005). Legal socialization of children and adolescents. Social Justice Research, 18(3), $217-241$.

Farrington, D. P., \& Loeber, R. (2000). Some benefits of dichotomization in psychiatric and criminological research. Criminal Behaviour and Mental Health, 10(2), 100-122.

Ferdik, F. V., Wolfe, S. E., \& Blasco, N. (2014). Informal social controls, procedural justice, and perceived police legitimacy: Do social bonds influence evaluations of police legitimacy? American Journal of Criminal Justice, 39(3), 471-492.

Ferdik, F. V., Gist, J., \& Blasco, N. (2016). Perceived police legitimacy: Investigating its association with collegebased informal social controls. Psychology, Crime \& Law, 22(3), 252-275.

Fishbein, M., \& Ajzen, I. (1975). Belief, attitude, intention, and behavior: An introduction to theory and research. Reading, MA: Addison-Wesley.

Flexon, J. L., Lurigio, A. J., \& Greenleaf, R. G. (2009). Exploring the dimensions of trust in the police among Chicago juveniles. Journal of Criminal Justice, 37(2), 180-189.

Gouveia-Pereira, M., Vala, J., Palmorani, A., \& Rubini, M. (2003). School experience, relational justice, and legitimation of institutional authorities. European Journal of Psychology of Education, 18(3), $309-325$.

Greene, C., Sprott, J. B., Madon, N. S., \& Jung, M. (2010). Punishing processes in youth court: Procedural justice, court atmosphere and youths' views of the legitimacy of the justice system. Canadian Journal of Criminology and Criminal Justice, 52(5), 527-544.

Hinds, L. (2007). Building police-youth relationships: The importance of procedural justice. Youth Justice, 7(3), $195-209$.

Hinds, L. (2009). Youth, police legitimacy and informal contact. Journal of Police and Criminal Psychology, 24(1), 10-21. 
Hoeben, E. M., Meldrum, R. C., \& Young, J. T. (2016). The role of peer delinquency and unstructured socializing in explaining delinquency and substance use: A state-of-the-art review. Journal of Criminal Justice, 47, 108-122.

Hough, M. (2013). Procedural justice and professional policing in times of austerity. Criminology and Criminal Justice, 13(2), 181-197.

Hough, M., Jackson, J., \& Bradford, B. (2013a). The drivers of police legitimacy: Some European research. Journal of Policing, Intelligence, and Counter Terrorism, 8(2), 144-165.

Hough, M., Jackson, J., \& Bradford, B. (2013b). Legitimacy, trust and compliance: An empirical test of procedural justice theory using the European social survey. In J. Tankebe \& A. Liebling (Eds.), Legitimacy and criminal justice: An international exploration (pp. 326-352). Oxford: Oxford University Press.

Jackson, J., \& Gau, J. M. (2016). Carving up concepts? Differentiating between trust and legitimacy in public attitudes towards legal authority. In E. Schockley, T. Neal, L. PytlikZilling, \& B. Bornstein (Eds.), Interdisciplynary perspectives on trust: Towards theoretical and methodological integration (pp. 49-69). New York: Springer.

Jackson, J., Bradford, B., Hough, M., Myhill, A., Quinton, P., \& Tyler, T. R. (2012). Why do people comply with the law? Legitimacy and the influence of legal institutions. British Journal of Criminology, 52(6), 10511071.

Kohlberg, L. (1992). Psicología del desarrollo moral. Bilbao: Descleé de Brouwer.

Krüger, N., Formichella, M. M., \& Lekuona, A. (2015). Más allá de los logros cognitivos: La actitud hacia la escuela y sus determinantes en España según PISA 2009. Revista de Educación, 367, 10-35.

Lurigio, A. J., Greenleaf, R. G., \& Flexon, J. L. (2009). The effects of race on relationships with the police: A survey of African American and Latino youths in Chicago. Western Criminology Review, 10(1), $29-41$.

Marshall, I. H., Enzmann, D., Hough, M., Killias, M., Kivivuori, J., \& Steketee, M. (2013). International SelfReport Delinquency Questionnaire 3 (ISRD-3): Background Paper to Explain ISRD2-ISRD3 Changes (Vol. 1). ISRD3 Technical Report Series.

Moreno, L. (2001). La «vía media» española del modelo de bienestar mediterráneo. Papers. Revista de Sociología, 63/64, 67-82.

Murphy, K. (2015). Does procedural justice matter to youth? Comparing adults' and youths' views willingness to collaborate with police. Policing and Society, 25(1), 53-76.

Murphy, K., \& Gaylor, A. (2010). Policing youth: Can procedural justice nurture youth cooperation with police? Alfred Deakin research institute, working paper 6. Australia: Deakin University.

Newburn, T., \& Reiner, R. (2012). Policing and the police. In M. Morgan y, R. Reiner (Eds.), The Oxford handbook of criminology (pp. 910-952). Oxford: Oxford University Press.

Nivette, A. E., Eisner, M., Malti, T., \& Ribeaud, D. (2015). The social and developmental antecedents of legal cynicism. Journal of Research in Crime and Delinquency, 52(2), 270-298.

Reisig, M. D., \& Lloyd, C. (2009). Procedural justice, police legitimacy, and helping the police fight crime: Results from a survey of Jamaican adolescents. Police Quarterly, 12(1), 42-62.

Reisig, M. D., Tankebe, J., \& Mesko, G. (2014). Compliance with the law in Slovenia: The role of procedural justice and police legitimacy. European Journal on Criminal Policy and Research, 20(2), 259-276.

Ren, L., Zhang, H., Zhao, J. S., \& Zhao, R. (2016). Delinquent subculture and juvenile offenders' attitudes toward the police in China. Police Quarterly, 19(1), 87-110.

Sabia, M. F. (2016). Predictability of delinquency through psychosocial and environmental variables across three generational status groups. Doctoral dissertation. Minneapolis: Walden University.

Sargeant, E., \& Bond, C. E. (2015). Keeping it in the family: Parental influences on young people's attitudes to police. Journal of Sociology, 51(4), 917-932.

Schuck, A. M. (2013). A life-course perspective on Adolescents' attitudes to police: DARE, delinquency, and residential segregation. Journal of Research in Crime and Delinquency, 50(4), 579-607.

Sprott, J. B., \& Greene, C. (2010). Trust and confidence in the courts: Does the quality of treatment young offenders receive affect their views of the courts? Crime \& Delinquency, 56(2), 269-289.

Stattin, H., \& Kerr, M. (2000). Parental monitoring: A reinterpretation. Child Development, 71(4), 1072-1085.

Steinberg, L. (2014). The science of adolescent brain development and its implication for adolescent rights and responsibilities. In J. Bhabha (Ed.), Human rights and adolescence. Philadelphia: University of Pennsylvania Press.

Tapp, J. L., \& Levine, F. J. (1974). Legal socialization: Strategies for an ethical legality. Stanford Law Review, $27(1), 1-72$.

Tyler, T. R. (1990). Why people obey the law. New Haven: Yale University Press.

Tyler, T. R. (2003). Procedural justice, legitimacy, and the effective rule of the law. In M. Tonry (Ed.), Crime and justice. A review of research, 30 (pp. 431-505). Chicago: University of Chicago Press. 
Tyler, T. R. (2006). Psychological perspectives on legitimacy and legitimation. Annual Review of Psychology, 57(1), 375-400.

Tyler, T. R., \& Fagan, J. (2008). Legitimacy and cooperation: Why do people help the police fight crime in their communities? Ohio State Journal of Criminal Law, 6, 231-275.

Van Damme, A., Pauwels, L., \& Svensson, R. (2015). Why do Swedes cooperate with the police? A SEM analysis of Tyler's procedural justice model. European Journal on Criminal Policy and Research, 21(1), 1533.

Warr, M., \& Stafford, M. (1991). The influence of delinquent peers: What they think or what they do? Criminology, 29(4), 851-866.

Weber, M. (1964). Economía y sociedad. Esbozo de sociología comprensiva. México: Fondo de Cultura Económica.

Wolfe, S. E., McLean, K., \& Pratt, T. C. (2016). I learned it by watching you: Legal socialization and the intergenerational transmission of legitimacy attitudes. British Journal of Criminology. https://doi. org/10.1093/bjc/azw038.

Wu, Y., Lake, R., \& Cao, L. (2015). Race, social bonds, and juvenile attitudes toward the police. Justice Quarterly, 32(3), 445-470. 